\title{
WHY DOES LANGUAGE CHANGE?
}

\section{By LEo SpITZER}

The question propounded in the title of this paper is a staggering one; it is a question that could find no answer, however tentative, so long as scholars in linguistics, faced with the common experience that time brings about changes in language, dwelt exclusively on the aspect of variation. Not until it was realized that historic change is characterized by a certain regularity conld such an attempt be made: it is the elemert of consistency within change that serves to cast light on the possible causes of change. Or, in the rnore circumscribed field a phonetic change: so long as the only phonetic criterion was the aesthetic correspondence of sound with meaning (for example, according to Varso the $h$ in horror was exceliently suited to express horror, the word mel was a fitting representation of the thing "honey"); ${ }^{2}$ so long as one failed to perceive that sound-shifts in different words take rlace with a certain regularity in a certain linguistic community and periad (and wth relatively little regard to the meaning of the particular word), the science of phonetics made no progress. But today any high-school boy possessing the rudiments of Latin and French may discover by himself the so-called "phonetic law" that Latin tonic long stressed $e$ in unchecked syllables evolves to Fr. $2 a$; and, if he should undertake to read Old French, he would ciscover that this $e$ passed regularly first to $e^{*}$, later to $o$, and still later to the, na $(r \bar{g} g e>r e i>$ roi > raté $>$ ruá).

The idea of the "phonetic law" (already latent in the discussions of certain isolated Renaissance scholars $)^{2}$ was first conceived, and the term itself coined, by Humbolat and Bopp: the former spoke of phonetische Gesetze, the latter, in words reminiscent of the aesthetic approach of the Greeks, of Wonllautregeln "rules of euphony"-an expression which he later changed to Wohlloutgesetze and then abridged to Lautgesetze. While, thanks to Humboldt, there

${ }^{x}$ Text of an address delivered to the Philological Association of the Johns Hopkins Faculty (December 11,1941). I have added the notes.

"C. Steinthal, "Geschichte der Sprachwissenschaft bei den Grieschen und Romern:" p. 340 seq. XII, 96 .

a $C^{f}$. R. A. Hall, "Linguistic Theory in the Ttalian Renaissance," Language,

"Cí. E. Wechssler, "Gibt es Lautgetze?" in Festschrift Suchier, who codified the neogrammarian thesis by reducing the sohere of phonetic change to a rather mythological dichotomy: Artikulotionstorsis and "Accent." Elise Richter would make accent responsible for the whole of Romance phonetics; cf. "Der innere Zusammenhang der romanischen Sprachen," Beiheft 27 of $Z R P h$. 
was brought into linguistics the philosophical idea of the Romantics that civilization develops like an organism, this Romantic idea was permitted to become curiously entwined with scientific positivism, under the growing influence of the natural sciences: thus the "phonetic laws" were supposed really to be "natural laws" which condition and explain the organic life of language. Such an assumption was challenged by Hugo Schuchardt ${ }^{5}$ in 1876: in his polemics against the "neo-grammarian" school at Leipzig, he clearly demonstrated that a phonetic law (such as the one $e>e i$ which we have just taken as an example) differs from a law of nature in that the former was active only in a certain area (e.g., France) and only for a certain period of time (e.g., 9-10 c.)-nor, even in that limited area and period was it binding for all words. Such a law, then, is not to be confused with, for example, the law of gravity which is always and everywhere equally efficacious (Schuchardt did not foresee our times, when the law of gravity itself would be considered no longer as based on causality but only on the law of averages!). Somewhat in the same vein Thurneysen, in his Rektoratsrede (1905) on "etymology," protested that sound-shifts in the different words never take place with the uniformity of a "goose-stepping row of Prussian grenadiers."

Since, according to Schuchardt, it is not legitinate to accept phonetic laws as representing blind, irresistible forces of nature, then these laws must be considered as themselves determined by deeper forces active in language. It is true that even the neogrammarian school allowed for the occasional intervention of the human mind: this is made responsible for the phenomenon of analogy, to which one must resort in order to explain, for example, the failure of the $e$ in habemus to develop in French as ue (*aveins); by analogy with sümus the form became *habummus (>nous avons). But Schtichardt believed that even in the so-called "regular" phonetic changes, analogy (i.e., mental influence) may be responsible: for example, in the development $e i>o i$ we witness a dissimilation of the first part of the diphthong $e$ into $o$ in order to break up the combination of two palatals: here we may trace a mental

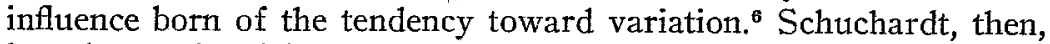
has the merit of having rescued phonetics from the infringement of the natural sciences upon the cultural; we philologists had credulously paid tribute to a transitory view of Nature, as held by

5 "Über die Lautgesetze." reprinted in my Schuchardt-Brevier.

"Schuchardt called this phenomenon "lautliche Analogie," and would explain thereby the Romance diphthongization (via the umlaut caused by final $-u,-i$ : originally buono buoni but bona). This theory of diphthongization has been revived by Schirr, Rom. Forsch., L, 275 and LIII, 27. 
naturalists-which is on no account to be confused with the Laws of Nature herself.

But while the belief in the absoluteness of the phonetic law was shaken, it could not be denied that phonetic changes appeared to be carried out in the different words with a relative regularity. Even the rounder of linguistic geography, Jules Gilliéron, who stoutly proclaimed the correctness of Schuchardt's slogan "Every word has its own history," did not fail to take these laws into account: he behaved with them much as we do today with the newspapersmistrusting them, scorning them, but using them. Thus a new problem arose: what accounts for this conformity, in practice, to certain, let us say, rales of phonetics?

Before this could be understood, it vas necessary that another fallacy in the positivism of the necgrammarians be corrected: they had treated the acoustically perceptible sotunds, as uttered by the spealing community, as if these were objective paipable phenomena lixe the hair and nails that grow on an organism. They failed to realize the obvious truth that human speech is primordiaily a psycrological activity, its source being in the mind of the speaker. The merit of having brotght phonetics back to psychology belongs to the Fussian, Baudouin de Courtnay who, in his lonely town of Kasan, was teaching, as early as 1868 , that the sounds as sense-data are not a psychological reality to the community: in the minds of a speaking group there is a psychological correspondent of the actual sound; this he called a "phoneme." To give a practical example: whenever I ask the colored waitress in our Faculty Club to bring me some snilk she looks at me blankly; her lack of comprehension I attribute to my 7 -sound; her conception of i evidently does not square with mine-which may still, I fear, be a rather German $l$.

Given this discrepancy between "sound" and "phoneme," the task of the linguist must be, not to catalogue the sounds which physicists can register with their apparatuses, but to inquire into the problem: which sounds are conceived as distinct by a community, and which groupings of phonemes are possible there? But scant attention was paid to the systematic and psychological approach as advocated by Courtnay until the day he found a posthumous ally in a book, itself posthumous: the Cours de linguistique générale (1915) written in Geneva by Ferdinand de Saussure in opposition to the German school ("Sprachwissenschaft ist Sprachgeschiche"-H. Paul); in this work Saussure rehabilitated the systematic and descriptive approach to language which had already been cultivated in the seventeenth century in France by the grammarians of Port-Royal. Thanks to this French-Swiss ally and to the 
spiritual by-products of emigration, Baudouin de Courtnay's ideas began to spread in Europe and America: the treatise of the Russianborn Sapir, "Sound Patterns in Language," opened the first volume of the American journal Language, in 1925; in Vienna, Prince Trubetzkoj published "Polabische Studien" in 1927; the Travaux $d u$ cercle linguistique de Prague soon followed. A new science was born: phonology as opposed to phonetics. ${ }^{7}$ Whereas the latter studies the possible acoustic phenomena which may be produced in all times and all places by human throats and mouths, the former treats of the actual conceptions of sounds as these have materialized in particular communities. Henceforth the "phonetic laws" must be transformed into phonological laws. To return to our milk: the sound pattern, phoneme, archetype of an American English $l-$ the "Platonic Idea" as it were of this sound in this countrydoes not comprehend the particular variant extant in German; and the naive mind of the waitress clings most tenaciously to the few platonic ideas, to the few abstractions, which it has been able to acquire-just as it would englobe in the idea "town" the American drugstore and exclude therefrom the European coffee-house.

Now we are able to understand the bearing which the phonological approach may have on historical linguistics. Prior to the emergence of any sound-shift there must have been a change in the mental pattern of the sound; hence the (heretofore unexplained) regularity of the sound-shift. Moreover, since any pattern of one sound is associated with others in our minds, other sound-shifts must occur when one pattern is displaced; this is what happened in the case of the German Lautverschiebung. What are the reasons for change in a pattern, or patterns, of sound? The historical school of the nirieteenth century gave as one of the most important reasons for sound-shift the contact between two populations with different ways of articulation, and the subsequent victory of one of these ways-or at least a compromise between the two; thus they would explain linguistic change by racial mixture. For example, the Romans who absorbed the Gaulish population of France were in their turn invaded by the Franks; the sound-shifts distinguishing French from Latin may be due in part to the Gaulish substratum, in part to the Frankish superstratum.

${ }^{7}$ On the phonological school, cf. Elise Richter, Die neueren Sprachen, XLI, 529; Puscariu, Etudes de linguistique roumaine (Cluj-Bucuresti, 1937); Trubetzkoj, Grundzige der Phonologie, 1939 (in Travaux...); Twadell, On defining the phoneme (Language Monographs, XVI, 1935) and the new journal Acta linguistica (issued first at Copenhagen, now at Geneva). 
To exemplify the latter, we may consider von Wartburg's explanation: ${ }^{8}$ according to him the tendency inherent in French to concentrate, with strong dynamic stress, on the tonic syllable, which entails the lengthening and diphthongization of vowels. the dropping of atonic vowels, the weakening of intervocalic consonents-all these changes ultimately go back to the heavy Germanic stress of the Ftanks. In this way change in accent, anima vocis, is made responsible for the various shifts in detal-and obviously this change of accent was due to the historical circumstance of racial mixt1re As for the Gaulish remnants in French, Ascoli and others explained the shifts $u>u_{,} a>e_{*} c t>i t$, together with the phenomenon of nasalization and the loss of atonic vowels, as vestiges of the speech habits of the autochthonous Celtic population; it was thought possible to bring the first three sourd-shifts in French under the one heading of palatalization. Meyer-Lübke ( inführung) took exception to Ascoli's $u>$ ii theory, since (as is indicated by the Norse place-names to be found in Frarce) this shift had not yet been achicved at the time when the Normans invaded France in the ninth century (accordingly this represents one of the most recent developments in pre-literary French), whereas the last vestiges of Gaulish as a spoken language in France date from the fifth century. Thus there was a gap of at least three centuries; the innovation in question appeared only 300 years after the Gaulish substratum had been completely assimiated.

"Language mixture", in the last third of the nineteenth century, served as the standard explanation of phonological change; indeed Sprachnischung was considered to represent the basic phenomenon in language -after Schuchardt had observed it at work throughout the Austro-Hungarian empire where he lived, and also in the Creole languages. One also maintained that this phenomenon could be of a social nature, occurring within one nation: the influence of a socially distinguished group conld explain the spread of a phonological shift. Did not the İashion of pronouncing a uvalar $r$ in Germany titimately derive from the French $r$ "grasseye" heard at the eighteenth-century Prussian cotrt, to spread ultimately throughout Germany thanks to the imposing social position enjoyed in this nation by the officers' corps? Moreover, the French grammarians of the sixteenth century har not failed to notice the exten-

$\beta$ "Die Ausgliederung der romanischen Spracträume" ( $Z$ sschr. f. rom. Spr., LVI seg.).

o Von Etmayer, Schuchardt's pupil, later was to say (and rightly) : "a man does not mix (anguages), he spealss!" Protests against Schuchardt's conception have recently been voiced by H. L. Koppeimann, "Ursachen des Lautwandels" (Leiden, 1939); cf. also my article on Ital. piagnistéo in Arch. rom., 1940. 
sion of the intervocalic $r>z$ sound-shift, which originated with the "mulierculae Parisinae... delicatulae" (mon mazi est à la porte de $P a z y) ;^{10}$ in a country where woman had risen to a place of increasing importance from the sixteenth century on, this pronunciation, which seemed to have about it a flavor of refinement, came to be adopted by the male population. Today Norwegian grammarians have observed the same phonologic tendency in Osloagain with the "mulierculae."

But there were also other attempts to explain sound-shift. Some theories appealed to a supposedly human tendency toward Bequemlichkeit, easy-goingness and relaxation-toward a minimum effort in pronunciation. But, if this was acceptable for explaining the so-called sporadic sound-shifts (assimilation, umlaut, etc.) as well as the weakening and dropping out of sounds, it was less so in those cases where complicated clusters developed out of simple sounds; when the gentle word amore (which, to Dante, seemed so consonant with its content) became, in Reto-romance dialects, amskr - this cannot be interpreted as a particularly convincing evidence of laxity in articulation. Indeed, such a tendency, unless checked by some opposing force, must inevitably lead to the total disintegration of human language as such. ${ }^{11}$

Again there were those who sought to follow a Montesquieuian trend of thought in admitting a direct influence of climate on phonology; today we quote as a joke the explanation that the blurred pronounciation of English was caused by the inhabitants' fear of inhaling the fog of their native land. But even in the subtler treatment of Father E. Schmidt and Koppelmann (the latter spoke in terms of "out-door" and "in-door" languages) ${ }^{12}$ the "climate"theory has never been adequately proved.

${ }^{10} \mathrm{Cf}$. Lerch, Jahrbuch fir Philologie, I, 80.

11. The same could be objected against Jespersen's principle of "progress" or "efficiency in linguistic change" (Copenhagen, 1941). If efficiency were the main explanation, why should not all languages become monosyllabic, even "monophonic"? Besides, the label "efficiency," as does also the essentially opposed "Bequemlichkeit," covers many particular attitudes: the shortening of hypocoristica (Fred. for Froderick) is, according to Jespersen, due to "efficiency"; but it is also an imitation of baby-talk which cuts words down to monosyllables. Thus, what prompts at least the rise of monosyllabic names is not efficiency but affection, i.e., a feeiing.

12 More specifically he establishes three variations: "Rufisprachen," "Diskretionssprachen" and "Intérieursprachen." The first, which is intended to be heard over long distances (from cliff to cliff, etc.) is characterized by a preponderance of vowels, in the Hawaiian language whole sentences may consist exclusively of vowels : ua, oia, $i a$, etc. But in my native $V_{1}$ enna, one may hear sentences shaped as follows (I want to induce my visitor to stay a little longer by telling him "later on I'm going to have to leave, too"): nacher far $i$ a $e$ a (nachher fahre ich auch ehe [sowieso] $a b$ ). 
Still others had recourse to biological factors: Eugen Herzog ${ }^{13}$ would make the sequence of generations responsible for sound-shift. But do not all normal children adequately learn the pronunciation of their elders? Nor has it ever been found that sound-shifts in general are the especial prerogative of adolescents. The Russian Roman Jakobson $^{14}$ has recently shown that the sound system of the child (of whatever nationality) builds itself up by stages: for instance $a$ and the labials precede the development of $r, l$, and these in turn are followed by the more complicated $t h, t s$; moreover, in the aphasic speech of the insane, the sounds tend to disintegrate in exactly the reverse order. However, to demonstrate the regularity with which complicated sounds develop out of those more simple is not to explain the tendency itself toward complexity: why complicate the sound patterns already at hand for the linguistic group? what induces a community to erect stumbling blocks for its own children, as the English have done with the sound th-which English children begin by pronouncing $f$, like any foreigner ${ }^{215}$

Finally, the Dutch schclar van Ginneken, supported by such scholars as Brondal and $\mathrm{E}$. Lewy, offered a theory concerning race and sound-shift. In order to bridge the gap of thtee hundred years, to which Meyer-Lübke had called attention, between the dying out of the Gaulish language and the appeararce of Fr. $u>\ddot{u}$, he applied Mendel's law, according to which racial peculiarities may come out only generations later: there could indeed have been a threecenturies period of linguistic incubation, during which the inherited Gatilish tendency is $>\ddot{u}$ was able to "sich ausraendeln." With such a theory we are in the midst of biological mysticisn; at one point he says: "la base d'articulation des Israelites est un fait indéniable." But this is very deniable: if there may be found German Jews who pronounce muechanisch with the -ach-, not the ich-sound, and with an " $e$ muet" (as in persent for Pereent), this "s conditioned by the teaching of Hebrews in Jewish communities (cf. Hebrew words

13 Sireitfragen der ramanischen Philologie (Halle. 1904).

14 "Kundersprache, Aphasie und allgemeine Lautgesetze" (Språkvetenskafligu Sällskonpets $i$ Uppsala Forhanditinger, 1940-41).

Is In Feone des études basques, XXV (1934), 353, I tried to show that the reason why the sound $\breve{c}_{s}$ genaine in Spanish only in the middle of the word (Lat. $-1 t-c_{-1}>c h$ an wheho, noche). lias spread over to the initial position (chaporrón) and to the pet sond for terms of endearment or, alternatively, of imprecation (Concha-diancho) is its affective appeal alone. This emotional appeal explasins also why foregn sounds (as inevitabiy introduced into any langunge by the loanwords, at least in the names $\alpha \overrightarrow{\mathrm{E}}$ foreign localities or personalities) may take root and spread in the language. Citizenship may also be given to umusual sounds-first only in onomatopeic words: for the Viennese arizerln "to urinate," the only word (except loan words from French, such as boniour) with a $x$ sound ir this dialect, ci. Revne des études indo-ewropéenes, I. 
with $e$ and $x+$ palatal vowel, i.e., by a cultural not by a racial factor.) Nor has the German of German Jews anything in common with the Spanish of Spanish Jews, for example: the one is mainly German, the other mainly Spanish $;^{16}$ and there is no common denominator. Even if the influence of race on language could be proved, we would still have no possibility of tracing this influence on any particular phonological development: if, after a racial mixture has been achieved, the expected sound-shift does not take place, van Ginneken will say that this is because Ausmendelung is still to bring it to light; and if after three centuries the sound-shift still fails to materialize, then van Ginneken will conclide that racial degeneration has taken place. ${ }^{.17}$

Those theories which treat of linguistic change as a result of social mixture, speak only of innovation, and innovation undertaken for the purpose of improving one's social standing. I have never liked that psychology of man as a social climber who, for worldly success and out of pure vanity alone, is an innovator in his speech. Is it not possible that the conservative instinct itself may lead to innovation? Perhaps, I thought, man creates because he wants to preserve, because he wants to be a good, undistinguished member of the linguistic community to which he belongs. In this case the real problen would be to find out the reason why this original conservative intention becomes eventually thwarted.

While ny thoughts were drifting along this line, I read the book of Don Ramón Menéndez Pidal, Orígenes del español (1926)this work whici, so far, has been the only one to explain the rise of any Romance national civilization and tongue, and which could have been written only by a polyhistor with a gigantic power of

1s Similariy, while Italian Jews are said to be recognizable by their unItalian * (grasseyé), Spanish Jews, on the other hand, roll their r's like any Spaniard. The main reason for the "separate" developments in Jewish languages all over the world is the (cultural) seclusion of these peoples, which is responsibie for preservation of archaisms.

Somewhat different, it seems to me, is the linguistic effect of seciusion on the Negro population in the United States : along with archasm there may also be involved a kind of préciosité in reverse, an all too w1lling adoption of latent tendencies in the English of the whites which the Negroes carry too far. a hypercorrectness.

17 For an excellent refutation of van Ginneken, cf. Koppelmann's book; especially convincing, it seems to me, is the argument drawn from the "wavetheory": if it be true, for example, that the Sp. $f>h$ development originated in the areas of Spain nearest to the Basque provinces. radiating southward therefrom (as Pidal has proved), then the different parts of Spain mist originally have been conscious of their (Iberian) inheritance in various degreesthose in the northernmost regions more so than those in the southern: for these did not at first adopt $f>h$. In E. Glässer's "Einfuhrung in die rassenkundliche Sprachforschung" (Heidelberg, 1939) the trick is used indiscriminately of ascribing to the tacial factor what has been proved to be a cultural influence on langtage. 
synthesis comparable to that of a Jakob Grimm. To understand Pidal's explanation of early diphthongization in Spanish and Romance, let us consider his treatment of open tonic $o$ in Romance (bowu). In this sound there are two elements present: the labial character of the vowel, and its open, stressed quality. The Spaniard of the eighth to tenth centuries, while uttering this vowel, concentrated his attention on these two elements separately, with the result that a split vowel was produced. And, in his attempt to pronounce a distinctly labial sound with the frst, he overdid himself: the excessive effort resulted in anuscular tension, and consequently, in a narrowing of the channel of the mouth; thereby the narrower, tenser wowel of was produced, giving the d:phthong $u t o$.

But, now that the labial quality of the vowel was sufficiently represented by the first element of the diphthong $(u)$, there was a tendency to neglect the labial character of the second sound, and to concentrate simply on the second element: on stress and openness. A relaxation of lakiality took place: úd feveloped into wé in Old Spanish and Old French; and in some Old Spanish and other Romance dialects we even find a $z_{0}^{\prime} \dot{x}$. In all these compounds there is maintained the stress on the second, although now altered, part of the diphthong; on the one land the spearing individual took care to proxounce a correct labial wowel (this explains the first exaggerated $u$ ); on the other, he wanted to pronounce a realy open sound (this explains his relative indifference to the articulation of the second part of $u \hat{\sigma}, u \dot{e}, u \dot{a})$. What was the reason for this double blunder? According to Pidal it was the need for expressivity, the desire to pronounce correctly, of thodoxly-but impressively.

Although Pidal does not elaborate on this paradoxical, psychological attitude, his introduction of the conception of expressivity seemed to me a most felicitous one; later, in ai article in Mélanges Salverda ale Grave (1933), I stressed expressivity as a main factor in phonology and, in the same year, independently from me, the young Swiss Kaspar Rogger developed similar ideas in his treatise "Vom Wesen des Lautwandels." 13 In the example given by Pidal, a conservative concern for the right pronunciation has led to outright revolution: the tendency toward linguistic orthodoxy, to a chaos which would have seemed barbatous to Cicero's ear-as barbarous as the diphthong-ridden English or German languages may appear to an Italian, used to the clear, unblurred, unified sounds of the bel canto of his own tongue. Intent as the early Spaniard was on preserving a pure $\underline{g}$, he has introduced an innovation-a revolutionist malgré lui.

1. I I Leipaiger romanische Studien, I (1933), 6 . 
But Pidal in his treatment of diphthongization failed to explain the primordial phenomenon involved: why, in fact, was one sound split into two (this is no necessary consequence of expressivity in itself); how was it that this one sound seemed to present two aspects, so that the speaker was led to tackle it in two instalmentshis "split attention" resulting in a split vowel? This undoubtedly reflects the awkward waverings of a people who had lost an instinctively sure linguistic taste: a state brought about, to some extent, by racial mixture, but mainly by conditions of cultural unrest.

We are faced here with the fact that languages and dialects are, as Vossler has said, "styles," ways of self-expression whereby a community manages to distinguish itself just as it may do in its literature, art, laws and institutions. It is interesting in this connection to note that while León and Aragon wavered longer between the different diphthongal developments $u o ́, u e ́, u d a$, Castile settled relatively early $\left(10^{\text {th }} \mathrm{c}\right.$.) on the one pronunciation $u e$ - which then came to be imposed on the rest of the country as the standard; in other words, Castile found her own classic style earlier than did other areas-in linguistics as in poetry; the others remained true longer to an archaic and chaotic style of self-expression which, as a basic phenomenon, is common to the Romance languages, all of which in fact are characterized by the break which they wrought in the unity and order of the Latin vocalic system. The "style" of Romance self-expression is rooted in restlessness and anarchy; the Romance peoples had not primarily wanted to innovate: they desired to preserve speech habits. But they had become unsure of themselves, self-conscious.

To take a parallel from linguistic development today: Hitler regularly opens his speeches by addressing his fellow-Germans as Deutsche Volksgenossen-pronouncing this with the two short open $o$ 's very close to $a$. And this personal sound-shift $Q>a$ represents for the linguist Hitler's personal reaction against the long closed $o$ pronunciation usual in the popular German of his native Austria: $V \overline{o l k}$, Genōsse. His Valksgenassen is in fact a hyper-correct pronunciation, influenced by his desire to speak good German. He is not trying to ape any one distinctive brand of German; he does not, for example, try to adopt the peculiarly Prussian pronunciation of $-g$ as $-\chi$ (der Ta $\chi$ ) ; he simply wants to speak pure German without traces of dialect. But the result is something which is neither dialect nor standard German, which betrays standard German while purporting to endorse $\mathrm{it}^{1.9}$ - and which ultimately reveals a cultural

${ }^{19}$ The same conclusions may be drawn concerning his initial $d$-, and the eu diphthong, which are neither quite Austrian nor quite standard German. 
uncertainty not far different from that mirrored in the linguistic behavior of the Spanish-Visigothic barbarians of an earlier age. This Hitlerian shift is the linguistic analogue to the Hypergermanism that underlies all of his doings: out of cultural weakness this $\varepsilon>a$ becomes a whipped-up expression of the energy and austerity of a corporal: a real parler gendarme as the French would say. And it might well happen that, if Hitler were allowed to remain a mational idol of Germany, the dominance with which he is invested, together with the levelling power of radio hroadcasting would lead to his innovation becoming the phonologic law for the whole of Germany; and such an innovation, just as was true of those occurring in early Romarce, would have been born out of a thwarted tendency toward conservatism.

Another example of overemphasis on orthodox pronunciation which leads to innovation ane is prompted by a lack of cultual assurance: standard French has a short palatal $a$ pronounced with the tongue slightly lifted toward the palate: patte. Madanne (as opposed to the velar $a$ in $\hat{p} \hat{a} t e, \hat{a m e}$ ). An affected Parisian pronunciation of this palatal a leads to $e$ : petté, Médème, Péris. This is a linguistic elegance of the uncultured, a kind of préciosité in reverse: the speaker wants to form a palatal $a$, but what cones out is an exaggerated $a$. It must not be thought that in this modern development there is a racially conditioned sound pattern at work; that we have to do with a repetition of the prehistoric $a>e$ shift (mare $>$ mer) which once took place in French; for, according to the observations of several scholars, made quite independently from each other, this $a>e$ shift is to be found (in the same strata of seciety as in Paris) in various urbar centers of Europe: in Copenhagen, The Hague, Prague, Istanbul. In this last city, I used to hear the newsboys calling out the evening paper $A k s c m$ with a most Paristan affectedness: Ekşem! With what gusto they seemed to twist their mouths to shape this sophisticated soind! Again we have to do with an innovation brought about by a desire to conform, to speak "naturally," and again this attempt faits, due to the impingement of cultural unrest; this effart to be natural which is met with today in the uprootedness of city life is itself, in a sense, unnatural. Now we can understand why the najor sound shifts in Romania took place before the year 1000 A.D.: in the period of the greatest cultural upheavals.

In all three cases of sound-shift just nentioned, it is undeniably true that there has been a "climbing" trend; obviously, the urge for conformity, conformity with a norm, is a token of a striving toward an ideal. And an ideal always is above us, as was well known to 
Dante, the creator of a Vulgare Illustre (which to his mind was doomed to be an ideal never reached by any dialect). But I believe that this striving toward the ideal, which is basic and permanent in man, is different from any occasional tendency toward social climbing.

Is this overemphasis on orthodoxy, so conducive to innovation, to be found in other fields of linguistic development? In semantics there are present the same two tendencies of conservatism and innovation, but the second, prompted by a desire to be impressive, undoubtedly is primary: regard for the accepted usage of the community acts rather as a check than as a creative motivating force. ${ }^{20}$

${ }^{20}$ It is not impossible, however, that under certain circumstances, exactly the same motivation may apply to semantic as to phonological innovation:

During the first world war I was attached to the central bureau of censorship concerned with the correspondence of Italian prisoners of war in Austria. These had, quite naturally, been forbidéen to write to their relatives in Italy that they were suffering hunger; consequentiy they made attempts to get this fact across in various periphrastic ways. The most effective, the orthodox, way to delude the censors would have been to insert, unobtrusively and once only, some common slang or dialect expression that would be unintelligible to the Tedeschi but clear to their people back home. But what they did in effect was to overindulge in periphrastic wording to an extent that had to arouse the suspicion of the censor. They were not content, for example, with a passing reference to la spazzala. "the brush" (lit. "[you may as well give me] the brush [to brush off the crumbs] [: there is nothing more to eat]") ; a typical letter would read thus ( $v$. my book, "Die Umschreibungen des Begriffes 'Hunger' im Italienischen," Haile, 1919) :

Give my love to the barber Gregorio and to the pharmacist Antonio and also to la signora Spazzola of whom I dream every night. I feel her near, but am never able to see her; and she will not let me sleep because she is not satisfied. . . .

This prisoner wanted his letter to sound orthodox, but, obsessed with the idea of censorship, he became over-ingenious and his excessive efforts to conceal caused him to betray himself by his manifold references to la sionora Spazzola He was no longer capable of giving a light touch but became as clumsy as the good-hearted bear in the fable who, desiring to swat the fly on his master's forehead, killed the master along with the fiy (indeed he even concludes his lyrical outburst by the advice: "have these words explained to you and you will understand"). In spite of his desire to stay within the bounds of conformity, he innovated stylistically, creating a. Dante-esque vision, an allegory of the Signora Spaszola: aut of a stock phrase grew poetry. It is as if the enjoyment of creativity overwhelmed this Italian private, and, giving rein to that delight in play and art with which the Italian people are endowed, he forgot about his own sad fate, and his practical purpose of communication (without detection), and came to think more of artistic expressivity. Now, expressivity obviously is enhanced by novelty: this Italian found la spazzola, after all, a trite paraphrase in the dull uniformity of his sermo castrensis, and, to restore new lustre to the phrase became more important for him than his original wish to be unobtrus've. As time went on, we were able to watch the dreary variations of this ghastly theme increasing in effusiveness and préciosité, in letters by all and sundry: "I have made the acquaintance of the lieutenants Spazzola, Magrini and Stecchetti"; "you say you want to send me a brush (spazzola) for my clothes: I don't need one: I have one with me. ever new, all the time; it is a nice spazzola"; "my health is good, but la spazzola works night and day, for there are many clothes to brush": "we have the brush, but not the grease to shine it with." And finally la Spazzola emerges as a force of destiny: "la spazzola here sounds its dull grey notes." 
And yet there is, paradoxically enough, something of conservatism even in the initial impulse to break with conservative usage: whereas in phonetic development there is an attempt to preserve the "perfect" sound, a semantic innovation seeks to preserve, or to restore, the original intensity of the idea-at the sacrifice of the verbal material.

Moreover in the field of semantics as in that of phonology the same cycle may be noted: first there is the period of creativity in which an individual innovation develops in expressivity, and expands; this period is followed in turn by one of standardization and petrification-which again brings about innovation and expressivity. Historical semantics offers us many parallels of the endless spiral movement in winich words that have ceased to be expressive give way to others. The first word in Latin for "to put, place" was facere, parallel to Gr. rit $\eta_{\mu}$; this was replaced (in historical Latin) by ponere [ $=$ po-sinere] which in its turn gave way to V.L. mittere (Fr. mettre); for mettre there was substituted in popular French the verb bouter (originally "to beat, slap") and this was duplicated by ficher "to stick" and its obscene companion-verb foutre. ${ }^{21}$ The history of the Future tense from Indo-European to Modern French involves a comparable succession of changes: the lise of the Latin Future $a m a b o$ in the place of the Indo-European Present; the Romance amare habeo (Fr. $j^{\prime}$ aimerai) ; Modern French je vais aimer -or, the simple Present, as in je pars denain (which may be evidence of a new cycle). To both these illustrations of the alter-

21 In the case of mettre replaced by foutre, one senses that into the pattern of "verb in -tre" was inserted fout-, as a suggestion of something more forceful. And even when the more refined would shun the use of this obscene word, it still shines through in such euphemisms as the infinitive fiche and the participle ficht-in which there is a reminder of foutre-foutu (cf. also dialectal boutre, after foutre). In such cases again the speaker is acting paradoxically: he conceais, and at the same time lets appear what he would conceal.

One might argue that in a semantic change such as mettres foutre "to put" there is not the conformism that obtains in the "expressive" sound-change $e i>o i$ (etc.); this is indeed a difference between semantic and sound change which will be pointed out later in the text. In order to maintain the energy of a sound, I may be allowed to go to the last extreme possible within the orbit of what can still be calied an approximate sound-whereas in semantics, I can, by means of association, cover a far longer stretch. Originally, a foutre is a word independent from meitre, and the effect of the metaphor that is achieved lies in the really violent identincation of "coire" with "ponere"; the $e i>$ oi development, on the other hard, implies no metaphoric procedure ( $b$ pro $a$ ), and no "violence."

With the semantic and metaphoric procedure involved in mettre $>$ foutre. the speaker takes a daring step before the community at least in the formative stage; the first time he says foutre for mettre, it is with an intonation suggestive of quotation-marks-as if, with this "purctuation" he would accomplish his duty toward the community ("you know, I am saying foutre, even though I know it is improper to say it"). 
nating tides of standardization and innovation in the flow of historic development, a parallel is offered in the phonological oscillation

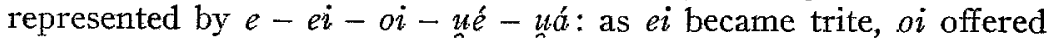
greater expressivity; as oi became standardized, úe was novelty, etc.

This inherent similarity between semantics and phonology, as regards the movement toward greater expressivity, is further borne out by the necessity, in either field, of a second factor in the period of creativity: once a semantic innovation creeps up somewhere (let us say under the influence of some linguistically creative individual), it will be quickly accepted on condition that it suits the community. Hans Sperber, in dealing with semantic innovation (in Einführung in die Bedeutungslehre, 1928), distinguishes between the "creative motive" and the "fixing factors": the former has need of the latter in order for the innovation to be ratified by the community. And the same is likewise true of phonological change: the "creative motive" responsible for the Hitlerian shift $q>a$ was probably simply his own personal desire to turn away from Austrian speech habits; but this pronunciation may well give an impression of military energy, and, if it should be imitated, this would be because of the type of ideal now (unfortunately) prevailing in Germany. Here we would have to do with the "fixing factor." Obviously, the possible development I suggest here is only a supposition on my part: it may happen in fact that the fixing factor I have postulated will prove unable to effect the development in question. And, as regards phonological shifts that became established centuries ago, it is even more difficult to separate the fixing factors from the creative motive. But it is nonetheless reasonable to infer that such factors must have been just as active as in semantics: why should millions of speaking individuals decide to adopt a given linguistic change unless this met some psychological need?

So far we have stressed the basic similarities in semantic and phonological change; in addition to the difference mentioned above, there are several others to be noted. In the first place, a phonological innovation is apt to be much less easily perceptible, since it develops very slowly; it took 500 years for the uá development to become standardized, and in 1000 years France has not been able completely to eradicate its $h$ aspiré borrowed from the Franks (the Hitlerian shift mentioned is an exceptional case: in one bound he achieves what might have taken 500 years in the course of natural phonologic evolution). A newly coined word or expression, on the other hand, or a new application of an old word (viz., ficher replacing mettre) has an immediately recognizable distinction, is completely achieved the first time it is used. As regards phonological innovations, because 
of the tenuous nature itself of such a change, and because of the fact that signs of this change will not be immediately indicated in writen texts, it is impossible to observe the beginnings of a sound-shift; to attempt to do so would be as chimerical as to seek to discover the exact moment at which a child grows up.

In the second place, phonological shift is marked by a regularity that may never be predicated of semantic change. Both, of course, are subject to limitation: one could hardly replace a verb meaning "to put, lodge" by one meaning "to take away, dislodge"-. nor cotld a Perfect take the place of a Future. But semantic development is beset by fewer restrictions than is phonological. While there are of course a number of possibilities for suggesting the acoustir effect of the sound $o$ or $e$, the possibilities for producing a semantic effect are still more vast: the associations of meaning upon which the human mind may seize are innumerable, not enclosed within a narrow orbit, as are phonological associations. Consequently it has been impossible to discover any semantic patterns parallel to the sound patterns that have been found to exist: these have offered such regularity as to invite the establishment of a system of "phonetic laws." But no one has ever thought of offering a "sernantic law," Hans Sperber has pointed out a slight analcgy with the phonological law, in the tendency by which the word coinages of an epoch are colored by the prevalent idiosyncrasies or complexes, but such tentative generalizations are a far cry from the rules of a Lautverschiebung.

As regards the paradigms of morphology (the declensions and conjugations; word-formations), these ofier more similarity with phonological phenomena. Morphology is in fact a kind of frozen semantics, the "patterns" of which are fairly regular; moreover the paradigms resemble sound patterns also in their relatively strong resistance to change. ${ }^{28}$ On the other hand morphology shows its kinship with semantics, in that morphological change is rooted in syntactical change (cf. the development of the future tense). This means that it is to be explained by reference to psychology; and, while the same must ultimately be true of phonological change as well, still, in out present state of knowledge, we are not able to isolate the psychological influence on phonological laws with the same assurance and precision that is possible in the case of semantics, syntax and morphology.

22 For example in a war period, all words, more or less, may take on a warlike tinge; in an aesthetic-minded epoch such as the Renaissance, the creation of such wordis as "taste" abounds.

23 We are all too prone to overemphasize change in our historical grammars; these tell us what has been changed, not what has been preserved-as, for examplc, that Fr. is est-ils sont still reflects an Indo-Exropean morphological pattern, or that the $p$-and the $-i$ - of pater remair in père. 
Investigation into these fields reveals phenomena that appeal more directly and intimately to the human psyche than do those of phonology; and it is probably for this reason that positivistic linguistics has considered phonological phenomena to be the most objective manifestations of human speech-quite unconnected, indeed, with the human mind. It was with phonetics that what we call modern linguistics ${ }^{24}$ began, and this historical procedure still betrays itself in the composition of our historical grammars: Volume I is regularly a Lautlehre; syntax is treated in the final volume; as for stylistics, this volume has usually remained unwritten. I would advocate, theoretically, the following order: first, an all-embracing stylistics (all historic change in language rests upon the urge to self-expression); next, syntax (which is stylistics grammaticised); then semantics and morphology. Only in the last volume would come phonology. ${ }^{25}$ I am well aware, of course, that such a scheme may appear utopian; but the difficulty (which I would be the last to deny) of succeeding in practice in relating every sound-shift to stylistics (or even a particular sound-shift to a particular trait of style) ${ }^{26}$ does not free us from the theoretical obligation of acknowledging the existence of this tie. Even if the calculations of Leverrier had not led in fact to the discovery of Neptune, they would still stand in their own right.

${ }^{24}$ The first attempts at a historical grammar which were not based on phonetics (Bopp, Raynouard, Grimm's first edition) would then not deserve this epithet.

${ }^{25}$ This is the reverse order of that chosen by Meyer-Lübke in his Einfuhrung who bases his characteristics of morphology and syntax in Italian and French on, so to speak, a primordial and "taken for granted" phonetic development which, in itself, does not seem to need any explanation. Cf. my Meisterwerke der roman. Sprachwissenschaft, II, 346.

26 If, for example, Schür is right in his theory of Romance diphthongization by umlaut (this would be supported by the existence of an older layer of diphthongs before $-i$; cf. Fr. and Prov. tiertz = tertius), the stylistic explanation would have to be quite different from that prompted by the theory of Pidal's; in such a case the slovenliness of uncultured barbatians at the beginning of the Middle Ages would be responsible. But, in order for such a "negative" quality to be active in language it must have become a positive one; there would have to have been an "ideal" of slovenliness-just as, in the French Revolution, it was due to the rise of a new republican ideal that the originally plebeian pronunciation $u \dot{a}$ became officially endorsed, and $u \dot{e}$ became the shibboleth of reactionarism.

All this is not to say that in every case of diphthongization the same stylistic explanation must obtain, I myself have pointed out (Bull. soc. ling., 1939) the particular diphthongization in American good by-e-e and other words as pronounced in a playful manner by women and implying a tacit understanding with the partner (consequently a split of attention leading to a split vowel); here, then, is a diphthongization born not of cultural unrest but. on the contrary, of a sure possession of the tool of language. One particular stylistic device can serve many purposes and, conversely, one stylistic intention can materialize in many linguistic embodiments. 
But if we are to base the whole of linguistics on style, if it is really true that nihil est in grammatica quod non fuerit in stylo, ${ }^{37}$ we may ask ourselves: what is the place of "style" in the scale of human values? If we heed the voice of Pascal, style is an sngodly thing: man has need of style, said this saint-who was a master of style and suasion-only because of his fall into sin, whereby he was bereft of the language of God; God needs no style in order to convince. According to his view, all out historical grammars of the nineteenth century, which have catalogued so carefuliy the vestiges of the manifold ways through which humanity has attermpted to express itseif-these, by virtue of exposing the very multiplicity of language-styles, would be orily monuments to the effects of post-Adamitic, Babylonian dispersal. Pascal, of course, was echoing the sentiment of Dante, as expressed in De vulgari eloguentia:

Curn igitur omnis nostra loquela, praeter ilam homini primo concreatam a Deo, sit a nostro beneplacito reparata post confusionem illam, quae nil î́uit aliud quam prioris oblivio, et homo. sit instalilisswun atque wariabilissinum animal, nec durabilis nec continua esse potest; sed sicut alia quae nostra sunt, puta mores et habitus, per locorum temporumque distantias variari oportet. Man, an unstable, shifting animal.. ${ }^{28}$

27 I first afvocated this thesis in Die neveren Sprocken. XXXII (1919), 323.

28 The particular human imperfection which is implied in my paradoxical thesis of a iypertension of attertion leading to innovation ${ }_{2}$ is the lack of proportion in the application of this attention by the speaking individual, the poor coordination of man's speaking abilities to the purpose in hand-a kind of Hegelian List der Idee. The "Christian pessimisn" of my theory (the frustration of good intentions) is far removed from the "idealistic" theory of Croce, for whom the imperfection of human speech (and, for him, spech is ectial to poetry) is "no problem" (ct. K. Vossler, "Benedetto Croces Sprachphilosophie" in Deutsche Viertal jalarschrift fr. Literaturwiss.

Georg Simmel. in his essay on "fashion" in the volume "Philosophische Kultur" (1911) writes as follows (this passage, Fr. 29, was called to my attention by Pedro Salinas):

Die Art, wie es uns gegeben ist, die Erscheinungen des Lebens aufizufassen, lässt uns an jedem Punkte des Daseins eine Mehrheit von Krafen fuhien, und zwar so, dass eine jede von diesen eigentlich über die wirlliche Erscheinung hinausstrebt, ihte Tnendlichkeit an der anderen bricht und in blosse Spannkraft und. Sehnsucht umsetzt. In jedem 'Tur, anch dem erschöpfendstea und fruchtbarsten, fuhien wir irgend etwas, was noch nicht ganz zum Ausdruck gekommen ist. Indem dies durch die gegenseitige Einschrankung der aneinander stossenden Elemente geschicht, wird an ihrem Dualismus gerade die Einheit des Gesamtlebens offenbar.

Simmel sees in fashion the paradaxical clash of the two conflicting forces with which we have been deang throughout this paper, self-distinction and conformism; moreover fashion; to him, may also be of a linguistic nature. While this perhaps could be said of the more ephemeral sound-shifts, viz. $16^{\text {th }} \mathrm{c}$. Fr. $r>z$, I can not agree with the wholesale theory 'sound-sinit = fashion' that is advocated by Jespersen and Sturtevant $e^{\frac{1}{1}}$ al. (Languge, XVT, 236). 
Modern linguistics has the one merit of seeking to retrace the erratic course of this wanderer-exiled from Eden. ${ }^{29}$

\section{The Johns Hopkins University}

${ }^{29} \mathrm{My}$ paper, based as it is on aesthetic and psychological considerations, will probably prove unpalatable to the anti-mentalistic school of linguistics. According to B. Bloch, Language, XVII, 351, "most American linguists probably agree with Bloomfield that a mentalistic approach to linguistic problems can only obscure the issue and 'short-circuit' inquiry." Iust how the anti-mentalists would reduce the aesthetic factor in linguistics to a matter of "unofficial" private taste ( - to the level, that is, of superstition, or some such inevitable residue of primitive human nature) is clearly brought out by the following lines of the same writer:

We can describe and codify the facts of language, and we can explain them within the framework of our science, by historical statements; to judge their usefulness or their beauty is to go outside that framework. This does not mean, of course, that a linguist is debarred by his profession from having opinions or tastes. In his unofficial [!] capacity as a human being and a user of language he can no more help [!] making judgments than anyone else.

The anti-mentalistic attitude has its origin in the fear of introducing "unknowns" into linguistics; it is no far cry from this attitude to that of denying the very existence of some basic factor of human speech because this factor is not easily traceable in detail; but, out of fear before the "unknown" that may be connected with a certain factor, to introduce the notion of its inexistence is to sin against the known, against knowledge itself. First one says: "let us not speak of the human mind because this would "obscure our notions" "; later one behaves as though this human mind did not exist at all; this would be an antiscientific, sophistical attitude: this is the attitude of this school of linguists who would prefer any mechanical and matter-of-fact explanation to a spiritual one. And to admit of a schism between the scholar-as-a-human being, and the "official scholar," as Bloch proposes, is to betray a lack of ambition toward the goal of a unification of human nature; it is a surrender to modern mental disintegration.

Ironically enough, the antimentalists seem to consider their pronunciamentos in favor of a fragmentary outlook on life to be the very paragon of scholarliness. Thus we learn by an authoritative statement of L. Bloomfield (Langnage. XIX, 170) that "philosophic passages have nothing to do in linguistic treatises"; they are "vestigial traits in culture," "shreds of medieval speculation"-whereas what is desirable is "rational and humane illumination." He does not seem to realize that such a statement itself constitutes a "philosophy" (albeit a very shallow decoction of eighteenth-century theories of the philosopkes) and that a linguistic treatise based on this anti-philosophic philosophy is necessarily bound to be a mentalistic philosophy (of the Leonard Bloomfield brand of mentalism. of course). I surmise that the antimentalists can only afford to call themselves "unbiased by philosophy" because they suppose that what they ignore (or are ignorant of ) can be eliminated at will and does not exist-in them, in spite of them.

In another passage (Language, XIX, 199) B. Bloch writes: "What 'mechanists' usually criticize in the work of 'mentalists' . . . is the circularity of their argument: the explanation of a linguistic fact by an assumed psychological process for which the only evidence is the fact to be explained." Such a statement betrays lack of familiarity with a current philosophical thought such as that expressed in Goethe's profound aphorism: "Das Höchste wäre zu begreifen $\mathrm{daB}$ alles Faktische schon Theorie ist." I suppose the antimentalists take it as a 
'fact. that there are such things as 'Proto-Romance,' 'Germanic languages,' without realizing that these "factual" expressions mply a theory, a speculation: indeed, there is here underlying the Goethian idea of the Urpflanze (an "unknown" () a principle not present in any particular branch but unfolding in them all. Thus the anti-mentalists do not hesitate to accept the results of speculation (when these have hecome commonplace, mechanized 'speech-habits'); they accept the canned fruit but reject the live tree of speculation itself; they comat to live on the dead residues of the past, not in the living present. And this achool would be a school of the future?

Furthermore the above-mentioned passage contains a reference to the "circularity of reasoning" characteristic of the mentalists, It is as if Schleiernucher and Dilthey had never taught that the "phitologischer Zirkelschluss" is he basic cperation in the humanitics: thus it was that Diez started with the observation (contrary to the assertion of Raynouard that Provençal was the mother language) that no one Ronance language is reducible to another, and then proceded to construct his "Trpflanze," the "unknown quantity" ProtoRomance $=V_{\text {ulgar }}$ Latin, finally concluding with the reverse procedure by which he Ferified his assumption that 'Vulgar Latin' as conceived by him, could explain all the Romance langiages. Notling is more orthodox than such "circuiar reasoning." Similarly, when I hate observed what I cali a "stylistic fact" (which is already a 'spectiation,' see above) in the language of a writer, I tentatively suggest a possible pisychological ront; in the writer, of this particulat usage-later to test whether the assund psyctiological root is able to explain other siy istic observations which nay be made concerning his individual language. (It is hardly correct to say that "the mentalists" base their psychological anatysis on ane fact alone) There is the same circularity here as in the reasoning of Diez: bofl speculations are in fact based on the 'idea' of the organicity of dewelogment (the 'organism' of Vulgar Iatin, 'the organism of the psyche of an individual writer - bcth of wich unfold, Of the two spectations, the bolder woufd seem to be the orse of Diez! Thus, far from being a logical error. as Mr. Bloch believes, the ctrcularity of argument is the rain ogeration in sciences of tine himan mind.

The anti-mentalistic bias which pervades the publications of the Linguistic Society of Anerica can be shown on nearly every page; I shall offer only che snecimen. In dissertation no. 17, "The Neute Plural in Vergil" (1934), J. F. Gumnere seets to prove by statistics that the use in Latin dactylic verse of the (nom. atd acc) pural of netuters is due to their greater metrical convenience; by analogy an "illogical" use of the plural in the thace of the singular was brought about, and "the so-cailed 'poetic' piturals are merely [1] these illogical phurals." He cites lines 645 seq. cif the Aeneid:

interiora domus inrumpit in inina, et altos conscendit furïunda rogos ensemque recludit

Dardaniutn, non hos quaesirum munus in 14 sts.

It apparently satisfies the unpoetic mind of this writer ("Du gleichst dem Geist, den du begreifst!") to see an ult?ma fokto in "metricai convenience"; this scems to him to be a causc sit, whereas the "poetic" qualities of ragueness, majesty, etc., are probably 'Hecuba to him. Any nomal human being could analyze this mythologem of "Inetrical convenience"-which introduces an "unknown" (of mentalistic origin at that) much more defrimental to the understanding of the linguistic phenonenon in question (which is the basis of the Vulgar Latin and Romance morphalcgical type gandia $>$ joite) than the legitimate. if diffcult, question of its psychological and aeshetic radix.

A healthy opposition to undisciplined mentaism is to be weicomed, but here the opposition has feyeloped into a wholesale negation of much of the finest thought in lirguistic philosophy since Herder. What a cruel self-mutilation of the haman mind! 